\title{
EVALUATION OF ALTERNATIVE ANIMAL PROTEIN SOURCES TO REPLACE FISHMEAL IN PRACTICAL DIETS FOR AFRICAN CATFISH (CLARIAS GARIEPINUS)
}

\author{
S. H. Mohsen ${ }^{1}$, A. K. I. El-Hammady ${ }^{2}$ and M. K. S. Taha ${ }^{2}$ \\ ${ }^{I}$ Department of Animal Production, Faculty of Agriculture, Al-Azhar University, Cairo. \\ ${ }^{2}$ Department of Fish Nutrition- National Institute of Oceanography and Fisheries, El-Kanater El- \\ Khyria, Kalubia Governorate, Egypt. \\ *akelhammady@yahoo.com
}

(Received 30/1/2017, Accepted 30/3/2017)

\section{SUMMARY}

$\mathrm{T}$ The Efficacy of replacing fish meal with fish waste meal, crayfish meal and gambusia fish meal on an ideal protein basis in diets for African catfish, Clarias gariepinus, were evaluated under production conditions in concrete ponds. African catfish averaging $325.21 \pm 3.99$ were randomly distributed among twenty outdoor concrete ponds subdivided (partitioned) by netting to 20 rearing units representing the twenty treatments studied. Each unit was $4.0 \mathrm{~m}$ length, $2.5 \mathrm{~m}$ width and $1.0 \mathrm{~m}$ depth $\left(10 \mathrm{~m}^{3}\right)$ freshwater at a stocking rate of 25 fish per rearing unit. Ten experimental diets isoprotein (37\%) and isocaloric diets $(19 \mathrm{KJ} / \mathrm{g}$ ) were formulated to contain three (3) animal source protein (Fish waste meal, Crayfish meal and Gambusia fish meal) at three (3) level of substitute of fishmeal (50, 75 and 100\%) and control diet in the experimental design .After 16 weeks (112 days), feed conversion efficiency and protein efficiency ratio decreased significantly $(\mathrm{p}<0.05)$ with increasing dietary fish waste meal substitution for fishmeal. The growth parameters indicated that weight gain, specific growth rate decreased significantly with increase in crayfish meal. The fish diet containing gambusia fish meal (75\%) and control diet had significantly $(p<0.05)$ higher weight gain, specific growth rate compared to other treatments. Based on the observed results, either of the tested products can be used to reduce the fishmeal content, when fish waste meal was available, $50 \%$ fish waste meal serviced as assailable partial replacement for fishmeal, though with crayfish meal was available the replacement of $50 \%$ of the fishmeal in basal diet African catfish with crayfish meal. However, the $75 \%$ gambusia fish meal in the present study is a suitable complete substitute for fishmeal in practical diets for African catfish. When three source of animal protein were availability, the gambusia fish meal (75\%) a suitable substitute for fishmeal in practical diets for African catfish (Clarias gariepinus).

Keywords: African catfish (Clarias gariepinus), fish waste meal, Cray fish meal, Gambusia fish meal, growth performance, feed efficiency.

\section{INTRODUCTION}

Catfish which belong to the family Claridae are the most cultured fresh water fish in Egypt. They are characterized by the ability to grow on a wide range of artificial and natural food, and they grow fast and have high yield potential, hardness and tolerance to dissolve oxygen in other aquaculture routine (Oresegun et al. 2007, Bake et al. 2015). The African catfish (Clarias gariepinus) are of great importance as esteemed food fishes especially to the rural populace in Egypt and in Africa. Hence, emphasis has been on the increase of how to improve productivity of catfish.

With the increase in channel catfish culture, there are greater demands for high protein supplemental feeds. Fishmeal, the primary source of animal protein in catfish feed, is quite expensive. Consequently, by substituting a cheaper source of animal protein the cost of catfish production could be reduced. Though , the profitability and success and of compound feed production depends on the costs, availability and digestibility of the feed ingredients to be used (Jimoh et al., 2014). 
Nutritive value of fish diet depends on quality of the protein ingredients used in diet formulation (Glen cross et al., 2007, Li et al., 2009). Protein is the most expensive component in fish feeds and the fishmeal is the major source of protein in fish diet (Mohanta et al., 2013). At present, fishmeal is not only expensive but also a scarce commodity due to its large demand in animal and fish feed industries (Akegbejq-samsons and Fasakin, 2008). Also, the feed stuffs of animal origins are considered better alternative protein sources to fishmeal in formulating fish diets, because of their higher protein content and the superior indispensable amino acids than that of plant origins. Several animal protein sources were evaluated to formulate the diets for different fish species such as fish waste meal (Sotolu, 2009), Gambusia, Gambusia affinis (Ahmed, 2008) and crayfish dust meal (Ojewola and Annah, 2006).

The quality and quantity of dietary protein are primary factor influencing growth and feed costs. Fishmeal (FM) is the most preferable and digestible protein source in the diet for most farmed fish due to its amino acids, fatty acids, energy, vitamins and minerals balance (Hasan et al.,2013,2016). Since the demand for fishmeal continues to grow, while its production is expected to remain constant (Borgeson et al., 2006), more attention must be paid to utilizing local material as an alternative protein source replacing fishmeal in the fish diet, for profitable fish production (Xuan et al.,2005).

In the central fish market, fish wastes and by -products are regularly generated which in clue heads, tails, viscera, scales and whey fish unsuitable for human consumption (Sotolu,2009). The same author showed that dietary fish waste meal at $15 \%$ inclusion level in catfish diets was better on the overall due to a superior economic conversion ratio it has over fishmeal $15 \%$ with marginal differences. Hasan et al. (2016) concluded that the salted trash fish could be included in the river catfish (Hemibagrus nemurus) diet up to $50 \%$ as replacement for $50 \%$ fishmeal without negative effect on growth performance, feed efficiency and proximate body composition of river catfish. However, Mosquito fish (Gambusia holbrooki and Gambusia affinis) have been introduction in to fresh water ecosystems around the world, often resulting in declines in native fish, invertebrate and amphibian population (Pkye, 2008). Walker et al. (1966) reported that crawfish waste when dried and ground into a meal could be useful as a protein and mineral supplement in catfish rations. The same author's found that the nitrogen, in the approximate composition of crawfish waste, is not all protein nitrogen. Perhaps 5 to 15 percent of the nitrogen is present as component of chitin shell and is of no known nutritional value to most animals. Ojewola and Annah (2006) examined nutritional and economic evaluation of the dietary inclusion Danish fishmeal, crayfish dust meal and shrimp waste meal as animal protein sources in broiler. To effectively minimize cost and facilitate increase production of aquatic product requiring protein dense diet, traditional fishmeal - based feeds must be reformulated to include the maximum amount of alterative protein yielding acceptable production performance (Mondal et al., 2008, Hardy, 1996).

Therefore, the main objective of the present study is to evaluat the utilize of some waste materials as alternative animal protein sources in formulating the diets of African catfish (Clarias gariepinus) and compared the growth and feed utilization performance of fish fed diet containing this protein source (fishmeal) with that of other protein sources (fish wastes meal, crayfish dust meal and gambusia fish meal).

\section{MATERIALS AND METHODS}

\section{Experimental location}

The experiment was carried out at the Fish Research Station, El-kanater El-khyria, Kalubia Governorate, of National Institute of Oceanography and Fisheries.

\section{Experimental design}

A complete randomized design was used in all the experiment, where treatments were of one variable, ingredient incorporates being the variable. The fishes and treatments were randomly assigned to rearing units in duplicate.

African catfish averaging 325.21 \pm 3.99 were randomly distributed among twenty outdoor concrete pond subdivided (partitioned) by netting to 20 rearing units representing the twenty treatments studied. Each unit was $4.0 \mathrm{~m}$ length, $2.5 \mathrm{~m}$ width and $1.0 \mathrm{~m}$ depth $\left(10 \mathrm{~m}^{3}\right)$ freshwater at a stocking rate of 25 fish per rearing unit. All fish were acclimated for two weeks during which fish were fed $3 \%$ feeding rate twice daily (9.00 am and 15.00 ) with $35 \%$ crude protein commercial diet, to prepare their appetite in readiness for the administration of the test diets. Each of the ten (10) experimental diets was tested in for a period of 16 weeks (112 days). Fish in all treatments were hand fed with dry pellets 6 days a week at 3\% body weight (BW) per day. A feeding rate of 3\% of body weight (biomass) twice a day(9.00 hr and $15.00 \mathrm{hr}$ ). Periodical evaluation of growth was done at fortnightly intervals the fish were bulk weighed and daily 
feeding rate were adjusted accordingly. Dead fish in each rearing unit were immediately removed and recorded.

Water quality parameters were daily checked and kept within satisfactory range (water temperature $29.35 \pm 2.01^{\circ} \mathrm{c}, \mathrm{pH} \quad 6.8 \pm 1.4$, dissolved oxygen $\left.5.6 \pm 1.3 \mathrm{mg} / \mathrm{L}, \quad \mathrm{N}-\mathrm{NH}_{3} \quad 0.14 \pm 0.05 \mathrm{mg} / \mathrm{L}\right)$. Natural photoperiod was $14 \mathrm{~h}$ light, respectively.

\section{Experimental diets}

Ten experimental diets isoprotein $(37 \%)$ and isocaloric diets $(19 \mathrm{KJ} / \mathrm{g})$ were formulated to contain three (3) animal source protein (Fish waste meal (Fwm), Crayfish meal (Cfm) and Gambusia fish meal $(\mathrm{Gfm})$ ) at three (3) level of substitute of fishmeal (50,75 and 100\%) and control diet in the experimental design (Table 1).

All ingredients, experimental diets in the beginning and the end of experiment and muscle fish were analyzed for the proximate composition according to standard methods (AOAC, 1990). The nitrogen free extract (NFE) was calculated by difference [100-(crude protein + crude lipid + crude fiber + Ash)] (Table 2). .

Gross energy based on the conversion factors; protein $23.41 \mathrm{KJ} / \mathrm{g}$; lipid $39.71 \mathrm{KJ} / \mathrm{g}$ and carbohydrate (as NFE) $17.56 \mathrm{KJ} / \mathrm{g}$ (Shiau and Liang, 1994).

Table (1): Design of the experimental diets.

\begin{tabular}{|c|c|c|c|c|c|c|c|c|c|c|}
\hline \multirow{3}{*}{$\begin{array}{l}\text { Item } \\
\text { Diet No }\end{array}$} & \multirow{3}{*}{$\begin{array}{c}\text { Control } \\
1\end{array}$} & \multicolumn{9}{|c|}{ Unconventional Ingredient of source protein } \\
\hline & & \multicolumn{3}{|c|}{ Fish waste meal } & \multicolumn{3}{|c|}{ Crayfish meal } & \multicolumn{3}{|c|}{ Gambusia fish meal } \\
\hline & & 2 & 3 & 4 & 5 & 6 & 7 & 8 & 9 & 10 \\
\hline $\begin{array}{l}\text { Percentage } \\
\text { Substitute }(\%) \\
\text { of crude protein } \\
\text { (fish meal) }\end{array}$ & - & 50 & 75 & 100 & 50 & 75 & 100 & 50 & 75 & 100 \\
\hline
\end{tabular}

Table (2): Proximate composition of the major ingredients used in the formulation of the experimental diet for C. Gariepinus (g/100g dry matter basis).

\begin{tabular}{lccccccc}
\hline Ingredient & $\begin{array}{c}\text { Dry } \\
\text { matter } \\
\%\end{array}$ & $\begin{array}{c}\text { Crude } \\
\text { Protein } \%\end{array}$ & $\begin{array}{c}\text { Ether } \\
\text { extract } \\
\%\end{array}$ & $\begin{array}{c}\text { Crude } \\
\text { Fiber\% }\end{array}$ & Ash\% & $\begin{array}{c}\text { Nitrogen } \\
\text { free } \\
\text { extract\%* }\end{array}$ & $\begin{array}{c}\text { Gross Energy } \\
(\mathrm{KJ} / \mathrm{g})\end{array}$ \\
\hline Fishmeal & 91.5 & 68.85 & 4.37 & 1.1 & 18.58 & 7.1 & 19.10 \\
$\begin{array}{l}\text { Soybean } \\
\text { meal }\end{array}$ & 90.8 & 48.46 & 1.21 & 6.61 & 6.06 & 37.66 & 18.44 \\
$\begin{array}{l}\text { Wheat bran } \\
\text { Yellow corn }\end{array}$ & 99.0 & 15.17 & 3.93 & 12.36 & 7.3 & 61.24 & 15.87 \\
$\begin{array}{l}\text { Fish waste } \\
\text { meal }\end{array}$ & 35.26 & 49.23 & 28.54 & 0 & 22.23 & 0 & 18.17 \\
$\begin{array}{l}\text { Crayfish } \\
\text { meal }\end{array}$ & 32.00 & 46.84 & 13.82 & 11.3 & $* * 28.04$ & 0 & 22.86 \\
$\begin{array}{l}\text { Gambusia } \\
\text { fish meal }\end{array}$ & 35.55 & 51.29 & 36.57 & 0 & 12.14 & 0 & 16.45 \\
\begin{tabular}{l} 
Fish Oil \\
\hline
\end{tabular} & 0 & 0 & 1 & 0 & 0 & 0 & 26.53 \\
\hline
\end{tabular}

*Nitrogen free extract calculated as $=100-\%($ moisture + crude protein + ether extract + ash + crude fiber $)$

**Crayfish meal ( $\mathrm{Ca}=0.89 ; \mathrm{P}=1.19$ ) according to Ojewola and Annah (2006) 


\section{Analytical methods}

The growth performance and feed utilization efficiency of fish were evaluated by determining the survival rate (\%); weight gain; specific growth rate (SGR;\%/day); feed conversion ratio (FCR); protein efficiency ratio (PER), protein, lipid and energy retention (\%) and were calculated as follows:

Weight gain $(\mathrm{g})(\mathrm{WG})=$ final weight - initial weight .

Specific growth rate $(\% /$ day $)(\mathrm{SGR})=\left(\mathrm{LnW}_{2}-\mathrm{Ln} \mathrm{W}_{1} / \mathrm{T}_{2}-\mathrm{T}_{1}\right) \times 100$.

Relative growth rate $(\%)(\mathrm{RGR})=\mathrm{W} 2-\mathrm{W} 1 / \mathrm{W} 1 * 100$.

Relative feed intake $(\%)(\mathrm{RFI})=$ feed intake $* 100 /(\mathrm{w} 2+\mathrm{w} 1) / 2 *$ time.

Feed conversion ratio $(\mathrm{FCR})=$ feed intake $(\mathrm{g}) /$ weight gain $(\mathrm{g})$.

Feed conversion efficiency $(\%)(\mathrm{FCE})=$ weight gain $(\mathrm{g}) * 100 /$ feed intake $(\mathrm{g})$.

Protein efficiency ratio $(\mathrm{PER})=$ weight gain $(\mathrm{g}) /$ protein intake $(\mathrm{g})$.

Protein retention $(\%)(\mathrm{PR})=$ protein gain $* 100 /$ protein fed.

Energy retention $(\%)(E R)=$ energy gain $* 100 /$ energy fed.

\section{Statistical analysis}

Data were analyzed according to a 3 X3 factorial design using the SAS General linear Models (GLM) procedure (SAS software version 8.2: SAS, 1999) for significant differences among treatment means when analyzed by protein source, substitute level, and their interaction. Duncan's multiple range test was used to compare differences among individual means at the $\mathrm{p}=0.05$ level of significance.

\section{RESULTS AND DISCUSSION}

In the present study our main objective was to develop nutritional balanced practical diets for the African catfish based on the nutrient requirement of this species using different alternate animal protein sources other than fishmeal. There, formulated ten practical diets using one control and three different animal protein sources with three level of partial or complete substitute incorporation of fishmeal.

Tables ( 3 and 4 ) show the proximate composition of the diets. Slightly differences in the moisture $(7.60 \pm 0.55 \%)$, crude protein $(37.07 \pm 0.59 \%)$, gross energy $(19.30 \pm 0.63 \mathrm{KJ} / \mathrm{g})$ and crude fiber $(6.93 \pm 0.41 \%)$ respectively. Furthermore, ether extract content varied 8.47 with diet control having the

Table (3): Formulation of the experimental diets for $C$. gariepinus (g/100g dry matter basis).

\begin{tabular}{|c|c|c|c|c|c|c|c|c|c|c|}
\hline $\begin{array}{l}\text { Ingredient } \\
(\mathrm{g} / 100 \mathrm{~g})\end{array}$ & Control & $\begin{array}{l}\text { Fwm } \\
50 \%\end{array}$ & $\begin{array}{l}\text { Fwm } \\
75 \%\end{array}$ & $\begin{array}{l}\text { Fwm } \\
100 \%\end{array}$ & $\begin{array}{l}\text { Cfm } \\
50 \%\end{array}$ & $\begin{array}{l}\text { Cfm } \\
75 \%\end{array}$ & $\begin{array}{l}\text { Cfm } \\
100 \%\end{array}$ & $\begin{array}{l}\text { Gfm } \\
50 \%\end{array}$ & $\begin{array}{l}\text { Gfm } \\
75 \%\end{array}$ & $\begin{array}{l}\text { Gfm } \\
100 \%\end{array}$ \\
\hline Fishmeal & 28 & 14 & 7 & 0 & 14 & 7 & 0 & 14 & 7 & 0 \\
\hline Soybean & 30 & 30 & 30 & 30 & 30 & 30 & 30 & 30 & 30 & 30 \\
\hline Wheat bran & 9.5 & 12 & 13.5 & 15 & 8 & 7 & 7 & 12 & 13.5 & 15 \\
\hline Yellow Corn & 24 & 18.42 & 15.63 & 12.84 & 17.42 & 14.13 & 10.84 & 19.22 & 16.82 & 14.43 \\
\hline Fish waste meal & 0 & 19.58 & 29.37 & 39.16 & 0 & 0 & 0 & 0 & 0 & 0 \\
\hline Crayfish meal & 0 & 0 & 0 & 0 & 20.58 & 30.87 & 41.16 & 0 & 0 & 0 \\
\hline $\begin{array}{l}\text { Gambusia fish } \\
\text { meal }\end{array}$ & 0 & 0 & 0 & 0 & 0 & 0 & 0 & 18.78 & 28.18 & 37.57 \\
\hline Fish Oil & 5.5 & 3 & 1.5 & 0 & 8 & 9.5 & 10 & 3 & 1.5 & 0 \\
\hline VitaminsPremix & 1.5 & 1.5 & 1.5 & 1.5 & 1.5 & 1.5 & 1.5 & 1.5 & 1.5 & 1.5 \\
\hline MineralsPremix & 1.5 & 1.5 & 1.5 & 1.5 & 1.5 & 1.5 & 1.5 & 1.5 & 1.5 & 1.5 \\
\hline \multicolumn{11}{|c|}{ 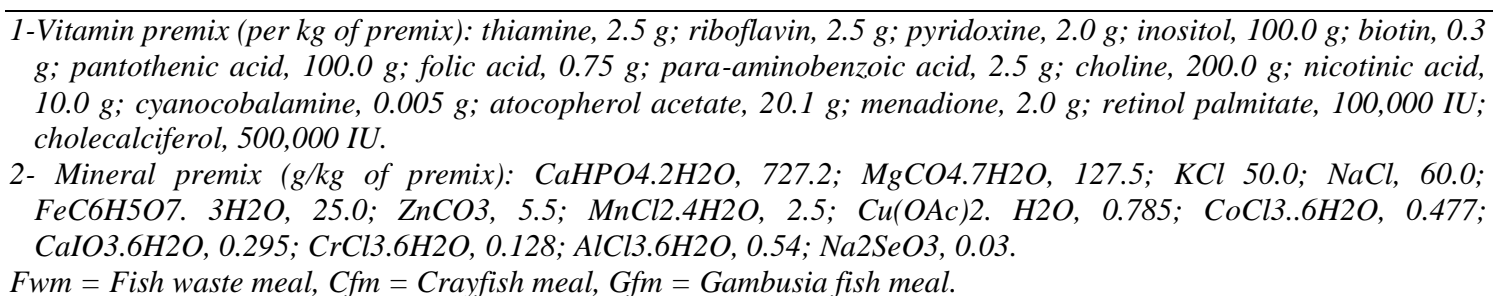 } \\
\hline
\end{tabular}


lowest value, while diet crayfish meal (14.78\%) and diet gambusia fish meal (100\%) (15.30\%) had the highest value respectively. Though both crude ash and nitrogen free extract content varied from $7.80 \%$ with diet gambusia fish meal $100 \%$ to $18.76 \%$ with diet crayfish meal $100 \%$, respectively for crude ash content. Though, from $24.40 \%$ with diet crayfish $100 \%$ to $38.62 \%$ with diet control, respectively.

Growth performance and survival of fish number of C.gariepinus fed with the different diets in experimental show in Table ( 5). Good survival rate of fish was achieved in all experimental diets (Table $5)$. In the present study, slightly differences $(\mathrm{P}>0.05)$ of survival fish number were observed between treatments . They attributed it to their good handling practice and water quality management throughout the experimental period (Muin et al.,2013). Swain et al. (2015) showed that the survival of fish depends on availability and type of feed, physico-chemical conditions of water. In this connection, Harron and Hossain (2001) found that the survival rate was about 100\% in cement cisterns and $94 \%-96 \%$ in earthen ponds as reported by Maniruzzamanin (2001). So, the survival of fish in the present study was found not to be influenced by different diets.

Table (4): Approximate composition of the experimental diets for C. Gariepinus (g/100g dry matter basis).

\begin{tabular}{|c|c|c|c|c|c|c|c|c|c|c|}
\hline $\begin{array}{l}\text { Proximate } \\
\text { analysis }\end{array}$ & Control & $\begin{array}{l}\text { Fwm } \\
50 \%\end{array}$ & $\begin{array}{l}\text { Fwm } \\
75 \%\end{array}$ & $\begin{array}{l}\text { Fwm } \\
100 \%\end{array}$ & $\begin{array}{l}\mathrm{Cfm} \\
50 \%\end{array}$ & $\begin{array}{l}\mathrm{Cfm} \\
75 \%\end{array}$ & $\begin{array}{l}\mathrm{Cfm} \\
100 \%\end{array}$ & $\begin{array}{l}\text { Gfm } \\
50 \%\end{array}$ & $\begin{array}{l}\text { Gfm } \\
75 \%\end{array}$ & $\begin{array}{l}\text { Gfm } \\
100 \%\end{array}$ \\
\hline Moisture & 8.59 & 7.78 & 7.4 & 7.03 & 7.63 & 7.12 & 6.72 & 8.11 & 7.9 & 7.69 \\
\hline Crude protein & 37.52 & 37.38 & 37.34 & 37.30 & 36.67 & 36.21 & 35.90 & 37.44 & 37.45 & 37.45 \\
\hline $\begin{array}{l}\text { Crude protein } \\
\text { (as feed) }\end{array}$ & 34.30 & 34.47 & 34.54 & 34.68 & 33.87 & 33.63 & 33.49 & 34.40 & 34.49 & 34.57 \\
\hline Ether extract & 8.47 & 10.81 & 11.74 & 12.67 & 12.87 & 15.31 & 14.78 & 12.13 & 13.71 & 15.30 \\
\hline Crude fiber & 7.13 & 7.13 & 7.16 & 7.19 & 8.94 & 9.81 & 6.15 & 7.15 & 7.20 & 7.24 \\
\hline Crude Ash & 8.25 & 10.06 & 10.98 & 11.90 & 10.32 & 12.60 & 18.76 & 8.00 & 7.90 & 7.80 \\
\hline $\begin{array}{l}\text { Nitrogen free } \\
\text { extract* }\end{array}$ & 38.62 & 34.62 & 32.77 & 30.93 & 31.36 & 26.70 & 24.40 & 35.27 & 33.74 & 32.22 \\
\hline $\begin{array}{l}\text { Gross } \\
\text { energy** }\end{array}$ & 18.93 & 19.12 & 19.16 & 19.20 & 19.17 & 19.13 & 18.85 & 19.77 & 20.14 & 20.50 \\
\hline $\begin{array}{l}(\mathrm{P} / \mathrm{E} \\
\text { ratio)**** }\end{array}$ & 19.82 & 19.55 & 19.49 & 19.43 & 19.17 & 19.26 & 19.34 & 18.94 & 18.59 & 18.27 \\
\hline Phosphorus & 0.74 & 0.77 & 0.75 & 0.81 & 0.93 & 1.02 & 1.12 & 0.69 & 0.73 & 0.73 \\
\hline
\end{tabular}

$*$ Nitrogen free extract $=100-\%($ Crude Protein + Ether extract + Crude fiber + Ash $)$

$* *$ Calculated using combustion values for crude protein, lipid and carbohydrate of $23.41+39.71+17.56 \mathrm{k} \mathrm{J}^{-1}$

respectively. According to (Shiau and Liang, 1994), ***(P/E ratio) $=m g C P / K J$

Fwm = Fish waste meal, Cfm = Crayfish meal, Gfm = Gambusia fish meal .

Data on growth performance are presented in Table (5) show that at the end of the 112 day feeding trial, the specific growth rate (SGR) gain weight and relative growth rate decreased significantly $(\mathrm{p}<0.05)$ with increase substitution of fish waste meal for fishmeal, and then declined $(\mathrm{p}<0.05)$ consistently from those of fish fed the control diet containing 100\% fishmeal. Though ,the average specific growth rate of African catfish was $0.73,0.66,0.64$ and 0.63 for diets with $0 \%$ (100\% fishmeal) $50 \%, 75 \%$ and $100 \%$ replacement by fish waste meal for fishmeal, respectively (Table 5). Among the different animal protein source used in the present study, (Table 5) the fish diet containing gambusia fish meal (75\%) and control diet had significantly $(p<0.05)$ higher weight gain, specific growth rate compared to other treatments.

In this connection Collazos and Guio (2005) and Sotolu and Faturoti (2008) reported that biological fish wastage supplementation to diet improved egg weight, weight gain, egg shell thickness and yolk percentage in laying Japanese quails. Though, the study by Balios (2003) and sotolu,(2009) revealed that fish by-product or fish waste meal are capable of supplying adequate nutrient or to high nutrient values as the imported fishmeal since both ingredients performed well at the same level which in clue $10 \%$ and $15 \%$ inclusions without any significant difference. Possible reasons for reduced growth of African catfish at partial or full replacement with fish waste meals in this study may be due to deficiencies in decreased protein composition and essential nutrients in the diets (Chitmanat et al.,2009). 
Table (5): Growth performance (means $\pm \mathrm{Sd}$ ) of $C$. gariepinus fed with the different diets in experimental.

\begin{tabular}{|c|c|c|c|c|c|c|c|c|c|c|}
\hline \multirow{2}{*}{ Item } & \multicolumn{9}{|c|}{ Treatment } & \multirow[b]{2}{*}{$\begin{array}{c}\text { Gfm } \\
100 \%\end{array}$} \\
\hline & Control & $\begin{array}{l}\text { Fwm } \\
50 \%\end{array}$ & $\begin{array}{l}\text { Fwm } \\
75 \%\end{array}$ & $\begin{array}{l}\text { Fwm } \\
100 \%\end{array}$ & $\begin{array}{l}\text { Cfm } \\
50 \%\end{array}$ & $\begin{array}{l}\text { Cfm } \\
75 \%\end{array}$ & $\begin{array}{c}\text { Cfm } \\
100 \%\end{array}$ & $\begin{array}{l}\text { Gfm } \\
50 \%\end{array}$ & $\begin{array}{l}\text { Gfm } \\
75 \%\end{array}$ & \\
\hline $\begin{array}{l}\text { Initial } \\
\text { weight } \\
(\mathrm{g})\end{array}$ & $\begin{array}{c}326.72 \\
\pm 8.31\end{array}$ & $\begin{array}{c}327.43 \\
\pm 7.69\end{array}$ & $\begin{array}{c}321.86 \\
\pm 9.23\end{array}$ & $\begin{array}{c}325.49 \\
\pm 8.33\end{array}$ & $\begin{array}{c}321.62 \\
\pm 7.45\end{array}$ & $\begin{array}{c}330.37 \\
\pm 9.73\end{array}$ & $\begin{array}{c}328.34 \\
\pm 8.85\end{array}$ & $\begin{array}{c}320.56 \\
\pm 7.09\end{array}$ & $\begin{array}{c}330.23 \\
\pm 8.25\end{array}$ & $\begin{array}{c}319.81 \\
\pm 9.07\end{array}$ \\
\hline $\begin{array}{l}\text { Final } \\
\text { weight } \\
\text { (g) }\end{array}$ & $\begin{array}{l}739.99^{b} \\
\pm 27.98\end{array}$ & $\begin{array}{l}685.66^{\mathrm{d}} \\
\pm 16.96\end{array}$ & $\begin{array}{c}666.43^{\mathrm{de}} \\
\pm 21.21\end{array}$ & $\begin{array}{l}658.95^{\mathrm{f}} \\
\pm 19.43\end{array}$ & $\begin{array}{l}644.01^{\mathrm{g}} \\
\pm 14.32\end{array}$ & $\begin{array}{l}661.4^{\mathrm{efg}} \\
\pm 25.69\end{array}$ & $\begin{array}{l}635.70^{\mathrm{h}} \\
\pm 13.64\end{array}$ & $\begin{array}{c}678.77^{\mathrm{fg}} \\
\pm 20.96\end{array}$ & $\begin{array}{r}766.6^{\mathrm{a}} \\
\pm 17.95\end{array}$ & $\begin{array}{l}708.32^{c} \\
\pm 25.29\end{array}$ \\
\hline Gain (g) & $\begin{array}{l}413.3^{\mathrm{ab}} \\
\pm 17.98\end{array}$ & $\begin{array}{l}358.26^{\mathrm{c}} \\
\pm 16.41\end{array}$ & $\begin{array}{l}344.26^{\mathrm{d}} \\
\pm 14.92\end{array}$ & $\begin{array}{l}333.53^{\mathrm{d}} \\
\pm 17.62\end{array}$ & $\begin{array}{c}322.41^{\text {ef }} \\
\pm 16.5\end{array}$ & $\begin{array}{c}331.13^{\mathrm{de}} \\
\pm 14.10\end{array}$ & $\begin{array}{l}307.40^{f} \\
\pm 17.51\end{array}$ & $\begin{array}{c}358.27^{\mathrm{cd}} \\
\pm 15.03\end{array}$ & $\begin{array}{l}436.4^{\mathrm{a}} \\
\pm 16.06\end{array}$ & $\begin{array}{c}388.52^{\mathrm{ab}} \\
\pm 14.39\end{array}$ \\
\hline $\begin{array}{l}\text { Specific } \\
\text { growth } \\
\text { rate } \\
(\mathrm{g} / \text { day } \\
\%)\end{array}$ & $\begin{array}{l}0.73^{\mathrm{ab}} \\
\pm 0.04\end{array}$ & $\begin{array}{l}0.66^{\mathrm{e}} \\
\pm 0.02\end{array}$ & $\begin{array}{l}0.64^{\mathrm{e}} \\
\pm 0.03\end{array}$ & $\begin{array}{l}0.63^{\mathrm{f}} \\
\pm 0.03\end{array}$ & $\begin{array}{l}0.62^{\text {fg }} \\
\pm 0.02\end{array}$ & $\begin{array}{l}0.62^{g} \\
\pm 0.03\end{array}$ & $\begin{array}{l}0.59^{\mathrm{h}} \\
\pm 0.02\end{array}$ & $\begin{array}{l}0.67^{\mathrm{cd}} \\
\pm 0.03\end{array}$ & $\begin{array}{l}0.75^{\mathrm{a}} \\
\pm 0.02\end{array}$ & $\begin{array}{l}0.71^{b c} \\
\pm 0.03\end{array}$ \\
\hline $\begin{array}{l}\text { Relative } \\
\text { growth } \\
\text { rate }(\%)\end{array}$ & $\begin{array}{c}126.5^{\mathrm{bc}} \\
\pm 8.56\end{array}$ & $\begin{array}{c}109.43^{\mathrm{f}} \\
\pm 5.18\end{array}$ & $\begin{array}{c}106.25^{\mathrm{fg}} \\
\pm 6.59\end{array}$ & $\begin{array}{c}102.50^{\mathrm{g}} \\
\pm 5.97\end{array}$ & $\begin{array}{c}100.25^{\mathrm{ef}} \\
\pm 6.54\end{array}$ & $\begin{array}{c}100.23^{\mathrm{g}} \\
\pm 7.7\end{array}$ & $\begin{array}{l}93.63^{h} \\
\pm 4.16\end{array}$ & $\begin{array}{c}111.77^{\mathrm{a}} \\
\pm 5.44\end{array}$ & $\begin{array}{l}132.1^{\mathrm{a}} \\
\pm 4.46\end{array}$ & $\begin{array}{c}121.5^{\mathrm{cd}} \\
\pm 7.91\end{array}$ \\
\hline $\begin{array}{l}\text { Survival } \\
\text { of fish } \\
\text { number }\end{array}$ & $23 \pm 2$ & $24 \pm 1$ & $24 \pm 1$ & $23 \pm 2$ & $22 \pm 3$ & $24 \pm 1$ & $22 \pm 3$ & $24 \pm 1$ & $23 \pm 2$ & $23 \pm 2$ \\
\hline
\end{tabular}

Means the same letter in the same row is not significantly different at $P<0.05$.

Fwm $=$ Fish waste meal, Cfm = Crayfish meal, Gfm = Gambusia fish meal.

Hasan et al. (2016) concluded that the salted trash fish could be included in the river catfish (Hemibagrus nemurus) diet up to $50 \%$ as replacement for $50 \%$ fishmeal without negative effect on growth performance, food utilization and proximate body composition of river catfish. The authors indicated to fact that at a low level of salted trash fish in the diet increased food consumption and weight gain was probably due to salt concentration of the diet which at a small amount (1.63\%) enhanced palatability of the diet. However, the fact that the inclusion of salted trash fish $>50 \%$ replacing fishmeal in the diet reduced weight gain, SGR, FCR and protein retention $(\mathrm{p}<0.05)$ might be due to higher concentration of salt in the diets $(>2.27 \%$ ) which reduced palatability of the diet, thus decreased food consumption weight gain and nutrient utilization. Also, Park et al.,(2000) reported that reduce growth in juvenile of flounder ( Paralichthys olivaceus) due to the excess amount of salt in the fish diets.

The growth parameters (Table 5) indicated that weight gain, specific growth rate decreased significantly with increase in crayfish meal. It clear that complete replacement of fishmeal with crayfish meal in African catfish, caused reduction of growth performance and feed efficiency, this may be contributed to increase crude fiber or chitin in diet from 10.32, 12.6 to 14.97 in treatments Cfm 50\%, Cfm 75\% and Cfm 100\%, respectively. Halver and Hardy (2002); Koprucu and Ozdemir (2005) reported that protein quality of dietary protein sources depends on the amino acid composition and their digestibility. Though, the same authors showed that deficiency of an essential amino acid leads to poor utilization of the dietary protein and consequently reduces growth and decreases feed efficiency. Ozdemir et al.(1999) also, who found that crayfish exoskeleton meal have high protein levels and favorable essential amino acid profiles, but ash and chitin contents of this feed ingredient are very high. In this connection, Koprucuand Ozdemir (2005) showed that apparent digestibility of dry matter, protein, average amino acid, lipid and energy in crayfish exoskeleton meal was significantly lower than those of other test ingredients (anchovy meal, corn gluten meal, soybean meal and gammarid meal to Nile tilapia . Koprucu and Ozdemir (2005) explained this trend may be due to high content of ash (30\% and 27\%, respectively) and chitin (10.2 and 6.6\%, respectively) in these ingredients. Lindsay, et al., (1984) indicated that chitin was not digested when feed at $10 \%$ and $30 \%$ of dietary rainbow trout. Though, Shiau and Yu (1999) revealed lower lipid and dry matter digestibility's of tilapia fed diets containing high chitin $(10 \%)$. In this connection, the differences in the bioavailability of phosphorus to salmonids and tilapia or crap is probably due to the limited secretion of gastric juices by these warm water species (Ogino, et al., 1979). Mohanta et al. (2013) showed that the chitin contents in the diets not measured, but percentage fiber in source protein (earthworm meal) which mostly represents its chitin content. 
On the other hand in the present study (Table 5) African catfish fed 75\% crayfish meal and 25\% fishmeal $(\mathrm{Cfm} 75 \%)$ had the least growth performance $(\mathrm{WG}=307 \mathrm{~g}, \mathrm{SGR}=0.59 \% /$ day $)$ and $(\mathrm{RGR}=$ 93.63\%), this suggests that chitin in crayfish meal has a growth promoting effect by producing glucosamine during its digestion through chitin as enzyme secreted by intestinal bacteria ( Ramanchandran Nair et al.,1987) in chicken, but the fish was poor in intestinal bacteria which may be increase chitin in diet caused decreasing in growth performance in fish. In this connection, Speen et al.(1984) observed that chitious material at lower levels supportsthe growth of bifidobacterium. Moreover, decreasing the growth performance and feed utilization with African catfish fed diets graduate crayfish meal $(50,75,100 \%)$ replacing for fishmeal on the crude protein basis, may be due to high fiber and ash contents of the diets (Table 4) which result in the formation of week pellets with poor stability in water, consequently diets could be loosed before fish taken (Chitmanat et al., 2009). According to Okoye (1998) and Ojewola and Annah (2006) showed that cray dust meal are by-products and relatively rich in calcium $0.89 \%$ and phosphorous $1.19 \%$. Though ,the phosphorus levels in the diets (Table 4 ) increased according the high level of phosphorus in crayfish meal added. It has previously been shown that the ratio of calcium and phosphorus may affect the growth of fish (Sakamoto and Yone ,1973). Rodehutscord et al.(2000) found that increased lipid digestibility with increased dietary phosphorus was study with rainbow trout. On the other hand, Hemre et al.(2003) reported that neither was the digestibility of lipid affected by dietary ash level.

The decrease of growth performance and feed efficiency of fish fed the fish waste meal and crayfish meal (Table 5 and 8) are in agreement with our finding for blue gourami, Trichogaster Trichopterus (Mohanta et al., 2013) fed fresh water fish processing wasted meal. The same authors showed that chitin in same animal protein sources might have responsible for poor performance of blue gourami. Similar to present observations, it is reported that growth depression and poor feed and protein utilization as well occurred in catfish fed with high levels of meal worm or solely on meal worms due to presence of chitin in the meal worms ( $\mathrm{Ng}$ et al., 2001). Olomu (1995) reported that crayfish is very tasty, and the combination of crayfish with Danish fishmeal in equal proportion could have enhanced the palatability of this diet, which in turn improved the intake. It clear increasing relative feed intake (2.38\%/day) of African catfish fed diets $75 \%$ of the protein fishmeal had been replaced by crayfish meal or a $25 / 75$ mixture of fishmeal and crayfish meal (Table 6). Then other treatments, except Gfm 75\% (2.52\%/day), respectively (Table 2). With respect to the percentage replacing, results (Table 6) showed that African catfish fed crayfish meal recorded increasing in relative feed intake (2.34\%/day) than either fish fed. Fish waste meal (2.32\%/day) and gambusia fish meal (2.27\%/day) respectively.

Table (6) show feed intake of $C$. gariepinus fed with the different diets in experimental. A negative linear correlation $(r=-0.86)$ was found between the amount of ash eaten (Table 6) and growth performance, while between the amount of ash eaten (Table 6) and feed conversion efficiency was $(\mathrm{r}=$ 0.88 ) for African catfish in present study fed graduated crayfish exoskeleton meal from 50, $75 \%$ up to $100 \%$ replacing by fishmeal in diets. On the other hand, Toppe et al., (2005) found that the highest inclusion level of bone meal (30.9\% ash) and crab meal (61.3\% ash $+11.3 \%$ chitin ), corresponding to the highest dietary levels of ash gave the best growth performances, as measured by weight gain and SGR, all showing significant positive linear correlations to the dietary ash level. Although the same authors reported that increased available phosphorus from the diet in experimental groups with added bone meal may explain the stimulated growth. This is in contrast with earlier work for salmon juveniles fed adliptum (Shearer et al., 1992) where increased dietary ash increased growth and feed intake but also seriously reduced feed efficiency ratio. In the same trend, Gatlin and Phillips,(1989) showed that reduced feed efficiency was also found by feeding high $\mathrm{Ca}$ diets to channel catfish. Though, with increased calcium levels in diets or with increased dietary level of bone meal in feed for juvenile gilthead sea bream (Robaina et al., 1997) growth was unaffected. Shearer et al., (1992) suggested that the tolerable level of ash in the diet for maximum growth and improved feed conversion probably depends on mineral composition and other nutrients present in diet. Similar to our findings (Table 5) by replacing $75 \%$ of dietary fishmeal with a Gambusia fish meal in a tendency toward increased growth performance and feed conversion efficiency.

Proximate composition of initial and final muscle of $C$. gariepinus fed with the different diets in experimental (g/ $100 \mathrm{~g}$ as dry matter basis) (Table 7). Fish muscle proximate composition shows decrease $(\mathrm{p}<0.05)$ in crude protein and increase $(\mathrm{p}<0.05)$ with increase fish waste meal replacing from $50 \%, 75 \%$ to $100 \%$ complete replace of fishmeal. In control treatment, the ether extract increased significantly than fish fed gradual ate fish wasted meal $(14.92,15.92$ and $21.02 \%$ for percentage replacement 50,75 and 100\%, respectively). Faturoti (2000) and Aderolu and Akinremi (2009) reported that the increasing fish carcass proteins and lipids with increase in dietary fishmeal inclusions. Skonberg et al. (1997) found that 
the ratio of calcium and phosphorus may be the cause in reducing body lipid for Cfm $100 \%$ group (Table ,7) .

Table (6): Feed intake (means $\pm \mathrm{Sd}$ ) of $C$.gariepinus fed with the different diets in experimental.

\begin{tabular}{|c|c|c|c|c|c|c|c|c|c|c|}
\hline \multirow[b]{3}{*}{ Item } & \multicolumn{10}{|c|}{ Treatment } \\
\hline & \multirow{2}{*}{ Control } & Fwm & Fwm & Fwm & $\mathrm{Cfm}$ & $\mathrm{Cfm}$ & $\mathrm{Cfm}$ & Gfm & Gfm & Gfm \\
\hline & & $50 \%$ & $75 \%$ & $100 \%$ & $50 \%$ & $75 \%$ & $100 \%$ & $50 \%$ & $75 \%$ & $100 \%$ \\
\hline \multirow{2}{*}{$\begin{array}{c}\text { Feed } \\
\text { consume } \\
\text { (g/fish) }\end{array}$} & $1149^{\mathrm{bcd}}$ & $1198^{\mathrm{ab}}$ & $1133^{\mathrm{cd}}$ & $1131^{\mathrm{cd}}$ & $1123.6^{\mathrm{e}}$ & $1148.7^{\mathrm{bcd}}$ & $1146.1^{\mathrm{bcd}}$ & $1261.4^{\mathrm{a}}$ & $1165.4^{\mathrm{bc}}$ & $1104^{\mathrm{e}}$ \\
\hline & \pm 19 & \pm 33 & \pm 31.6 & \pm 36.9 & \pm 42 & \pm 38.1 & \pm 23 & \pm 39.8 & \pm 40.5 & \pm 27.5 \\
\hline \multirow{2}{*}{$\begin{array}{c}\text { Relative } \\
\text { feed } \\
\text { intake }(\%)\end{array}$} & $2.15^{\mathrm{c}}$ & $2.37^{\mathrm{b}}$ & $2.29^{\mathrm{b}}$ & $2.30^{\mathrm{b}}$ & $2.33^{\mathrm{b}}$ & $2.32^{\mathrm{b}}$ & $2.38^{\mathrm{b}}$ & $2.52^{\mathrm{a}}$ & $2.13^{\mathrm{c}}$ & $2.15^{\mathrm{c}}$ \\
\hline & \pm 0.04 & \pm 0.08 & \pm 0.07 & \pm 0.05 & \pm 0.04 & \pm 0.06 & \pm 0.08 & \pm 0.07 & \pm 0.06 & \pm 0.07 \\
\hline \multirow{2}{*}{$\begin{array}{l}\text { Protein } \\
\text { intake } \\
\text { (g/fish) }\end{array}$} & 431.2 & 447.9 & 423.2 & 422.0 & 420.7 & 412.4 & 415.0 & 472.4 & 436.4 & 404.8 \\
\hline & \pm 7.25 & \pm 12.34 & \pm 11.78 & \pm 13.77 & \pm 15.74 & \pm 13.67 & \pm 8.33 & \pm 14.89 & \pm 15.16 & \pm 10.1 \\
\hline \multirow{2}{*}{$\begin{array}{c}\text { Fat intake } \\
\text { (g/fish) }\end{array}$} & $97.3^{\mathrm{d}}$ & $129.5^{\mathrm{c}}$ & $133.0^{\mathrm{c}}$ & $143.3^{\mathrm{bc}}$ & $136.3^{c}$ & $169.8^{\mathrm{ab}}$ & $158.3^{\mathrm{abc}}$ & $172.9^{\mathrm{a}}$ & $178.3^{\mathrm{a}}$ & $131.1^{\mathrm{c}}$ \\
\hline & \pm 1.64 & \pm 3.57 & \pm 3.70 & \pm 4.68 & \pm 5.09 & \pm 5.63 & \pm 3.18 & \pm 5.45 & \pm 6.19 & \pm 3.26 \\
\hline \multirow{2}{*}{$\begin{array}{l}\text { Fiber } \\
\text { intake } \\
\text { (g/fish) }\end{array}$} & $81.96^{\mathrm{abc}}$ & $85.46^{\mathrm{abc}}$ & $81.18^{\mathrm{abc}}$ & $81.39^{\mathrm{abc}}$ & $100.5^{\mathrm{abc}}$ & $112.7^{\mathrm{bc}}$ & $123.8^{\mathrm{bc}}$ & $90.77^{\mathrm{a}}$ & $84.35^{\mathrm{abc}}$ & $73^{\mathrm{bc}}$ \\
\hline & \pm 1.38 & \pm 2.36 & \pm 2.26 & \pm 2.66 & \pm 3.01 & \pm 2.34 & \pm 1.46 & \pm 2.86 & \pm 2.93 & \pm 1.82 \\
\hline \multirow{2}{*}{$\begin{array}{c}\text { Carbohydr } \\
\text { ate intake } \\
\text { (g/fish) }\end{array}$} & $443.8^{\mathrm{a}}$ & $414.9^{\mathrm{abc}}$ & $371^{\mathrm{bcd}}$ & $349.9^{\mathrm{cd}}$ & $396^{\mathrm{abc}}$ & $280.3^{\mathrm{e}}$ & $316.04^{\mathrm{de}}$ & $425.6^{\mathrm{ab}}$ & $375.4^{\text {abcd }}$ & $346^{\text {cde }}$ \\
\hline & \pm 7.46 & \pm 11.43 & \pm 10.34 & \pm 11.42 & \pm 14.83 & \pm 9.29 & \pm 6.34 & \pm 13.42 & \pm 13.05 & \pm 8.61 \\
\hline \multirow{2}{*}{$\begin{array}{c}\text { Ash intake } \\
\text { (g/fish) }\end{array}$} & $94.79^{\mathrm{g}}$ & $120.5^{\mathrm{def}}$ & $124.5^{\mathrm{de}}$ & $134.7^{\mathrm{cd}}$ & $116.0^{\mathrm{g}}$ & $144.8^{\mathrm{a}}$ & $171.6^{\mathrm{b}}$ & $100.9^{\text {efg }}$ & $90.85^{\mathrm{g}}$ & $86.11^{\mathrm{c}}$ \\
\hline & \pm 1.59 & \pm 3.32 & \pm 3.46 & \pm 4.39 & \pm 3.36 & \pm 7.15 & \pm 3.70 & \pm 3.14 & \pm 3.16 & \pm 3.70 \\
\hline $\begin{array}{l}\text { Energy } \\
\text { intake }\end{array}$ & $217.5^{\mathrm{ab}}$ & $229.1^{\mathrm{ab}}$ & $217.1^{\mathrm{ab}}$ & $217.3^{\mathrm{ab}}$ & $215.4^{\mathrm{ab}}$ & $219.8^{\mathrm{ab}}$ & $216.1^{\mathrm{ab}}$ & $254.1^{\mathrm{a}}$ & $238.9^{\mathrm{ab}}$ & $207.7^{\mathrm{b}}$ \\
\hline (KJ /fish) & \pm 3.66 & \pm 6.31 & \pm 6.05 & \pm 7.09 & \pm 8.31 & \pm 7.07 & \pm 4.32 & \pm 8.01 & \pm 6.19 & \pm 5.17 \\
\hline
\end{tabular}

Means the same letter in the same row is not significantly different at $P<0.05$.

Fwm = Fish waste meal, Cfm = Crayfish meal, Gfm = Gambusia fish meal .

In the present study, nutrients utilization of $C$. gariepinus fed with the different diets in experimental show in Table (8). The results of FCR and the differences between these values were not significant as affected source protein (Fwm, Cfm, Gfm) and percentage substitute $(50,75,100 \%)$ are presented in Table (8). Though, these results showed the best FCR's were recorded by fish of treatments Gfm 75\% (2.67) than control diet and other treatments. While poorest FCR (3.73) was record by fish fed Cfm. Though, from the present study showed that FCR (Table 8) depend on the source of dietary protein used in the experiments. In agreement with the previous result the reported by earlier workers, found that the feed conversion ratio (FCR) values varied very widely for various fish when they fed diets containing different animal protein sources (1.78 -2.93) for Nile tilapia, with fermented feather meal ( Arunlertaree and Moolthongnoi (2008), 1.82 -1.96 for African catfish, Clarias gariepinus, with fish waste meal and fishmeal (Sotolu , 2009), 1.27 -2.40 for C. gariepinus with blood meal ( Agbebi and Otbusin, 2009, and Otubusin et al,2009); 2.64 -2.75 for $C$. gariepinus with rendered animal protein (Akegbejo- sansons and Fasakin (2008). Furthermore, feed conversion efficiency and protein efficiency ratio decreased significantly $(\mathrm{p}<0.05)$ with increasing dietary fish waste meal substitution for fishmeal (Table 8$)$. This observation is consistent with Chitmanat et al. (2009) who reported that fish by-product powder could 
substitute for fishmeal on a crude protein basis at a level of not more than $25 \%$. The superior performance suggests that more nutrients rich in amino acids are made available for fish to utilize since both are from fish source (Sotolu, 2009). The same author found that weight gain, FCR and PER of African catfish improved as dietary fish waste meal inclusions increased from $10 \%$ to $15 \%$.

Table (7): Proximate composition (means \pm Sd) of initial and final muscle of $C$. gariepinus fed with the different diets in experimental ( $\mathrm{g} / 100 \mathrm{~g}$ as dry matter basis).

\begin{tabular}{|c|c|c|c|c|c|c|c|c|c|c|c|}
\hline \multirow{3}{*}{ Item } & \multicolumn{11}{|c|}{ Treatment } \\
\hline & \multirow{2}{*}{ Initial } & \multirow{2}{*}{$\begin{array}{c}\text { Contro } \\
1\end{array}$} & \multirow{2}{*}{$\begin{array}{l}\text { Fwm } \\
50 \%\end{array}$} & \multirow{2}{*}{$\begin{array}{l}\text { Fwm } \\
75 \%\end{array}$} & \multirow{2}{*}{$\begin{array}{l}\text { Fwm } \\
100 \%\end{array}$} & \multirow{2}{*}{$\begin{array}{l}\mathrm{Cfm} \\
50 \%\end{array}$} & \multirow{2}{*}{$\begin{array}{l}\mathrm{Cfm} \\
75 \%\end{array}$} & \multirow{2}{*}{$\begin{array}{c}\text { Cfm } \\
100 \%\end{array}$} & \multirow{2}{*}{$\begin{array}{l}\text { Gfm } \\
\mathbf{5 0 \%}\end{array}$} & \multirow{2}{*}{$\begin{array}{l}\text { Gfm } \\
\mathbf{7 5 \%}\end{array}$} & \multirow{2}{*}{$\begin{array}{r}\text { Gfm } \\
100 \%\end{array}$} \\
\hline & & & & & & & & & & & \\
\hline \multirow{2}{*}{ Moisture } & 77.3 & $74.54^{b}$ & $75.66^{\mathrm{ab}}$ & $74.48^{b}$ & $75.92^{\mathrm{ab}}$ & $76.07^{\text {ab }}$ & $74.95^{\mathrm{ab}}$ & $77.60^{\mathrm{a}}$ & $75.66^{\mathrm{ab}}$ & $76.68^{a b}$ & $76.41^{\text {ab }}$ \\
\hline & \pm 0.7 & \pm 1.32 & \pm 1.59 & \pm 2.04 & \pm 1.95 & \pm 1.54 & \pm 1.506 & \pm 0.96 & \pm 1.35 & \pm 0.524 & \pm 2.86 \\
\hline \multirow{2}{*}{$\begin{array}{l}\text { Crude } \\
\text { protein }\end{array}$} & 70.6 & $72.06^{\mathrm{e}}$ & $80.59^{a}$ & $79.61^{a}$ & $74.89^{d}$ & $75.48^{\text {cd }}$ & $74.29^{d}$ & $80.46^{\mathrm{a}}$ & $77.25^{\mathrm{bc}}$ & $74.94^{d}$ & $78.86^{\mathrm{ab}}$ \\
\hline & \pm 0.04 & \pm 0.19 & \pm 0.66 & \pm 1.29 & \pm 0.54 & \pm 2.287 & \pm 0.872 & \pm 1.507 & \pm 0.882 & \pm 1.61 & \pm 3.67 \\
\hline \multirow{2}{*}{$\begin{array}{l}\text { Ether } \\
\text { extract }\end{array}$} & 23.8 & $23.91^{a}$ & $14.92^{\mathrm{e}}$ & $15.92^{\text {cde }}$ & $21.02^{b}$ & $20.02^{b}$ & $20.74^{b}$ & $15.07^{\text {de }}$ & $17.45^{\mathrm{c}}$ & $20.26^{b}$ & $17.09^{\text {cd }}$ \\
\hline & \pm 0.03 & \pm 0.25 & \pm 0.47 & \pm 1.12 & \pm 0.52 & \pm 2.018 & \pm 0.889 & \pm 1.396 & $\pm \mathbf{0 . 8 3 9}$ & \pm 1.457 & \pm 3.58 \\
\hline \multirow{2}{*}{ Ash } & 5.6 & $4.03^{\mathrm{f}}$ & $4.49^{\mathrm{de}}$ & $4.47^{\mathrm{de}}$ & $4.10^{f}$ & $4.37^{\mathrm{e}}$ & $4.97^{b}$ & $4.48^{\mathrm{de}}$ & $5.31^{\mathrm{a}}$ & $4.80^{b c}$ & $4.05^{\mathrm{f}}$ \\
\hline & \pm 0.48 & \pm 0.07 & \pm 0.322 & \pm 0.17 & \pm 0.04 & \pm 0.305 & \pm 0.057 & \pm 0.114 & \pm 0.049 & \pm 0.213 & \pm 0.152 \\
\hline \multirow{2}{*}{ Energy } & 26.0 & $26.36^{\mathrm{a}}$ & $24.79^{\mathrm{e}}$ & $24.96^{\mathrm{de}}$ & $25.88^{b c}$ & $25.67^{\mathrm{bc}}$ & $25.63^{\mathrm{bc}}$ & $24.82^{\mathrm{e}}$ & $25.01^{\mathrm{de}}$ & $25.59^{c}$ & $25.25^{\mathrm{d}}$ \\
\hline & \pm 0.01 & \pm 0.05 & \pm 0.089 & \pm 0.15 & \pm 0.08 & \pm 0.269 & \pm 0.15 & \pm 0.203 & \pm 0.128 & \pm 0.205 & \pm 0.56 \\
\hline
\end{tabular}

Means the same letter in the same row is not significantly different at $P<0.05$.

$F w m=$ Fish waste meal, Cfm = Crayfish meal, Gfm = Gambusia fish meal .

After 112 days, there was significant difference $(\mathrm{p}<0.05)$ in growth performance and feed efficiency $(\mathrm{p}<0.05)$ among African catfish fed graduate percentage replacing fishmeal with gambusia fish meal (Table5 and 8) muscle body proximate composition did differ $(\mathrm{p}<0.05)$ among fish fed gambusia meal (Table 7). SGR, RGR, FCR, FCE and PER of African catfish fed diets in which 75\% of the fishmeal had been replaced by gambusia fish meal was increased significantly $(\mathrm{p}<0.05)$ than those fed 50 and $100 \%$ gambusia fish meal and also fed the control diet. Abdelghany (2003) found that growth performance of red tilapia (Oreochromis niloticusx O. Mossambicus) fed diets containing gambusia meal $50 \%$ level of replacement for fishmeal, and this diet had the best economic efficiency of fish weight gain. In the present study, high growth performance and improve feed efficiency with fish fed 75\% gambusia meal may be due to amino acid balance in this diet (NRC,1993). However, the growth performance reduction in fish group fed diet containing $100 \%$ gambusia meal (Table 5) can be attributed to anti- nutritional substances such as thiaminase ( an enzyme that degrades thiamin, NRC,1983) may exist in gambusia fish meal which could be a factor at higher inclusion levels. Though, the growth reduction in African catfish (Table 5) fed the diet containing $100 \%$ gambusia fish meal may be contributed to decrease palatability of the diet causing a reduce feed intake (in turn fish growth )(Ahmed (2008) and Abdelghany (2003). Similar results were reported by Ahmed (2008) who recommended that gambusia fish meal is a suitable protein source in practical diets of fry Nile tilapia and could replace fishmeal up to $75 \%$.

Based on the observed results, either of the tested products can be used to reduce the fishmeal content, when fish waste meal was available, 50\% fish waste meal serviced as assailable partial replacement for fishmeal, though with crayfish meal was available the replacement of 50\% of the fishmeal in basal diet African catfish with crayfish meal. However, the $75 \%$ gambusia fish meal in the present study is a suitable complete substitute for fishmeal in practical diets for African catfish. When three source of animal protein were availability, the gambusia fish meal (75\%) a suitable substitute for fishmeal in practical diets for African catfish (Clarias gariepinus). 
Table (8): Nutrients utilization (means $\pm \mathrm{Sd}$ ) of $C$. gariepinus fed with the different diets in experimental.

\begin{tabular}{|c|c|c|c|c|c|c|c|c|c|c|}
\hline \multirow{3}{*}{ Item } & \multicolumn{10}{|c|}{ Treatment } \\
\hline & \multirow{2}{*}{ Control } & \multirow{2}{*}{$\begin{array}{l}\text { Fwm } \\
50 \%\end{array}$} & \multirow{2}{*}{$\begin{array}{l}\text { Fwm } \\
75 \%\end{array}$} & \multirow{2}{*}{$\begin{array}{l}\text { Fwm } \\
100 \%\end{array}$} & \multirow{2}{*}{$\begin{array}{l}\text { Cfm } \\
50 \%\end{array}$} & \multirow{2}{*}{$\begin{array}{l}\text { Cfm } \\
75 \%\end{array}$} & \multirow{2}{*}{$\begin{array}{l}\text { Cfm } \\
100 \%\end{array}$} & \multirow{2}{*}{$\begin{array}{l}\text { Gfm } \\
50 \%\end{array}$} & \multirow{2}{*}{$\begin{array}{l}\text { Gfm } \\
75 \%\end{array}$} & \multirow{2}{*}{$\begin{array}{l}\text { Gfm } \\
100 \%\end{array}$} \\
\hline & & & & & & & & & & \\
\hline \multirow{2}{*}{ FCR } & $2.79^{b}$ & $3.34^{\mathrm{a}}$ & $3.29^{\mathrm{a}}$ & $3.38^{\mathrm{a}}$ & $3.48^{\mathrm{a}}$ & $3.47^{\mathrm{a}}$ & $3.73^{\mathrm{a}}$ & $3.51^{\mathrm{a}}$ & $2.67^{b}$ & $2.84^{\mathrm{b}}$ \\
\hline & \pm 0.14 & \pm 0.22 & \pm 0.27 & \pm 0.30 & \pm 0.47 & \pm 0.33 & \pm 0.12 & \pm 0.29 & \pm 0.13 & \pm 0.12 \\
\hline \multirow{2}{*}{ FCE } & $35.92^{\mathrm{a}}$ & $30.00^{\mathrm{b}}$ & $30.58^{\mathrm{b}}$ & $29.74^{\mathrm{b}}$ & $29.15^{\mathrm{b}}$ & $29.04^{\mathrm{b}}$ & $26.86^{\mathrm{b}}$ & $28.61^{b}$ & $37.50^{\mathrm{a}}$ & $35.27^{\mathrm{a}}$ \\
\hline & \pm 1.82 & \pm 1.91 & \pm 2.48 & \pm 2.73 & \pm 2.18 & \pm 2.7 & \pm 0.85 & \pm 2.45 & \pm 1.81 & \pm 1.46 \\
\hline \multirow{2}{*}{ PER } & $0.96^{\mathrm{a}}$ & $0.80^{\mathrm{bcd}}$ & $0.82^{\text {bcd }}$ & $0.80^{\mathrm{bcd}}$ & $0.78^{\mathrm{cd}}$ & $0.81^{\mathrm{bcd}}$ & $0.74^{\mathrm{d}}$ & $0.76^{\mathrm{d}}$ & $1.00^{\mathrm{a}}$ & $0.96^{\mathrm{a}}$ \\
\hline & \pm 0.05 & \pm 0.05 & \pm 0.06 & \pm 0.08 & \pm 0.11 & \pm 0.08 & \pm 0.02 & \pm 0.06 & \pm 0.05 & \pm 0.12 \\
\hline \multirow{2}{*}{ FER } & $4.24^{\mathrm{ab}}$ & $2.78^{\mathrm{cd}}$ & $2.60^{\mathrm{de}}$ & $2.35^{\mathrm{ef}}$ & $2.40^{\mathrm{ef}}$ & $1.96^{\mathrm{g}}$ & $1.95^{\mathrm{g}}$ & $2.09^{\mathrm{fg}}$ & $2.45^{\mathrm{def}}$ & $2.97^{\mathrm{c}}$ \\
\hline & \pm 0.21 & \pm 0.18 & \pm 0.21 & \pm 0.22 & \pm 0.35 & \pm 0.18 & \pm 0.06 & \pm 0.18 & \pm 0.12 & \pm 0.12 \\
\hline \multirow{2}{*}{ EER } & $1.90^{\mathrm{a}}$ & $1.57^{\mathrm{b}}$ & $1.60^{\mathrm{b}}$ & $1.55^{\mathrm{b}}$ & $1.47^{\mathrm{b}}$ & $1.56^{\mathrm{b}}$ & $1.43^{\mathrm{b}}$ & $1.42^{\mathrm{b}}$ & $1.83^{\mathrm{a}}$ & $1.88^{\mathrm{a}}$ \\
\hline & \pm 0.10 & \pm 0.10 & \pm 0.13 & \pm 0.14 & \pm 0.21 & \pm 0.14 & \pm 0.04 & \pm 0.12 & \pm 0.09 & \pm 0.08 \\
\hline \multirow{2}{*}{ PR } & $19.34^{\mathrm{a}}$ & $18.32^{\mathrm{ab}}$ & $19.80^{\mathrm{a}}$ & $15.80^{\mathrm{bc}}$ & $15.38^{\mathrm{c}}$ & $17.02^{\mathrm{abc}}$ & $14.92^{\mathrm{c}}$ & $16.14^{\mathrm{bc}}$ & $18.57^{\mathrm{ab}}$ & $19.82^{\mathrm{a}}$ \\
\hline & \pm 1.60 & \pm 2.00 & \pm 2.33 & \pm 2.31 & \pm 1.52 & \pm 1.92 & \pm 0.96 & \pm 1.63 & \pm 0.38 & \pm 2.85 \\
\hline \multirow{2}{*}{ ER } & $50.68^{\mathrm{a}}$ & $37.09^{\mathrm{bc}}$ & $38.13^{\mathrm{bc}}$ & $39.60^{\mathrm{bc}}$ & $36.83^{\mathrm{bcd}}$ & $39.29^{\mathrm{bc}}$ & $33.67^{\mathrm{d}}$ & $34.07^{\mathrm{cd}}$ & $46.22^{\mathrm{bc}}$ & $46.15^{\mathrm{b}}$ \\
\hline & \pm 1.20 & \pm 1.24 & \pm 1.63 & \pm 1.52 & \pm 1.23 & \pm 1.17 & \pm 0.79 & \pm 0.88 & \pm 0.58 & \pm 2.84 \\
\hline
\end{tabular}

Means the same letter in the same row is not significantly different at $P<0.05$.

$F w m=$ Fish waste meal, Cfm = Crayfish meal, Gfm = Gambusia fish meal .

$F C R=$ Feed conversion ratio, FCE $=$ Feed conversion efficiency\%, PER = Protein efficiency ratio,

$F E R=$ Feed efficiency ratio, EER = Energy efficiency ratio, $P R=$ Protein retention, ER= Energy retention $\%$

\section{REFERENCES}

Abdelghany, A. E. (2003). Partial and complete replacement of fish meal with gambusia meal in diets for red tilapia Oreochromisniloticus $\times$ O. mossambicus. Aquacult. Nutr. 9:145-154.

Aderolu, A.Z. and O.A. Akinremi (2009). Dietary Effects of Coconut oil and peanut oil in improving Biochemical characteristics of Clarias gariepinus juvenile. Turkish J. Fisheries and Aquatic Sci., 9: 105-110.

Agbebi O.T., S.O. Otubusin, F.O. Ogunleye (2009). Effect of different levels of substitution of fishmeal with blood meal in pelleted feeds on catfish Clarias gariepinus (Burchell, 1822) culture in net cages. Euro J Sci Res 31: 6-10.

Ahmad, M. H. (2008). Evaluation of gambusia, Gambusia affinis, fish meal in practical diets for fry Nile tilapia, Oreochromis niloticus. J. World Aquac. Soc. 39:243-250.

Akegbejo-Samsons Y.,and A.E. Fasakin .(2008). Use of rendered animal protein meals as fish meal replacer in the diets of the African catfish, Clarias gariepinus (Burchell, 1822) juveniles. Tropicult 26: 89-92.

AOAC (1990). Official Methods of Analysis, Association of Official Analytical Chemists, 15th ed., Inc. Arlington, Virginia.

Arunlertaree C., C .Moolthongnoi .(2008). The use of fermented feather meal for replacement of fish meal in the diet of Oreochromis niloticus. Env Nat Resour J 6: 14-24. 
Bake, G. G., A. A .Yusuf, M.Endo, Y. Haga, S.Satoh, S. O. E. Sadiku, and T. Takeuchi, (2015). Preliminary investigation on the inclusion of fermented Sickle pod Senna obtusifolia seed meal as an ingredient in the diet of Clarias gariepinus fingerlings. Int. J Curr Res Biosci Plant Biol, 2(8), 70-80.

Balios, J.,( 2003). Nutritional value of fish by-products and their utilization as fish silage in the nutrition of poultry. Proceedings of the 8 International Conference on Envir. Sci. and Technol. Lemnos Island, Greece. 8-10 September 2003.

Borgeson T. L., V. J. Racz., D. C., Wilkie., L. J .White.and M. D., Drew ( 2006). Effect of replacing fishmeal and oil with simple or complex mixtures of vegetable ingredients in diets fed to Nile tilapia (Oreochromis niloticus). Aquaculture Nutrition 12:141-149.

Bureau, D.P., A.M. Harris, C.Y. Cho. (1999). Apparent digestibility of rendered animal protein ingredients for rainbow trout (Oncorhynchus mykiss). Aquaculture 180, 345-358.

Bureau, D.P., A.M. Harris, D.J. Bevan, L.A. Simmons, P.A. Azevedo, and C.Y. Cho.(2000). Feather meals and meat and bone meals from different origins as protein sources in rainbow trout (Oncorhynchus mykiss) diets. Aquaculture 181, 281-291.

Chitmanat C., A. Tipin, P. Chaibu, and S. Traichaiyaporn.(2009). Effects of replacing fishmeal with wastes derived from local fisheries on the growth of juvenile tilapia, Oreochromis niloticus. Sonklanakarin Journal of Science and Technology, 31(1), 105.

Collazos, H. and C. Guio. (2005). The effects of dietary biological fish silage on performance and egg quality of laying Japanese quails (Coturnix coturnix japonica). $16^{\text {th }}$ Symposium on Poultry Nutrition.

Dada A.A. and C. Wonah. (2003). production of exotic Clarias gariepinus at varying stocking density in outdoor ponds. Journal of aquatic science 18(i): pp21-24

FAO. (1995). Fishery information, data and statistics. Aquaculture Production 1983-1993, FAO Fish. Circ. 815 (rev. 7). 186 p.

Faturoti, E.O. ( 2000). Beneath the ripples and sustainable fish production. Inaugural lecture, University of Ibadan, pp: 54.

Forster, I. (1999). A note on the method of calculating digestibility coefficients of nutrients provided by single ingredients to feeds of aquatic animals. Aquaculture Nutrition 5, 143-145.

Gatlin, D.M. and H.F. Phillips, (1989). Dietary calcium, phytate and zinc interactions in channel catfish. Aquaculture 79, 649-656.

Glen cross B.D, M. Booth, and G.L. Allan. (2007). A feed is only as good as its ingredients-a review of ingredient evaluation strategies for aquaculture feeds. Aquacult Nutr 13: 17-34.

Halver, J.E. and R.W .Hardy. ( 2002). Fish nutrition, Third edition. Academic Press, New York. 824 pp.

Hardy RW (1996) Alternate protein sources for salmon and trout diets. Anim Feed Sci Technol 59: 71-80.

Haroon A.K.Y. and M.R.A. Hossain. (2001). Studies on the polyculture of Pangasius sutchi (Fowler) in cemented cisterns. Final report on post flood rehabilitation and adaptive research support project. Bangladesh Fisheries Research Institute, Chandpur and Bangladesh Agricultural Research council, Dhaka, 12-18

Hasan, B.i., I. Putra, I.Suharman and D. Iriani. (2016). Evaluation of salted trash fish as a protein source replacing fishmeal in the diet for river catfish (Hemibagrus nemurus) AACL Bioflux, 2016, Volume 9, Issue 3.

Hasan B., I. Suharman , I. D. Desmelatin (2013) .An improvement of carcass quality characteristic of farmed baung catfish (Mystus nemurus) for smoked catfish processing through dietary protein and energy formulation]. Lembaga Penelitian Universitas Riau Pekanbaru, pp. 167-171. [in Indonesian]

Hemre, G. I., Ø. Karlsen, A. Mangor-Jensen, and G. Rosenlund. ( 2003). Digestibility of dry matter, protein, starch and lipid by cod, Gadus morhua: comparison of sampling methods. Aquaculture 225, $225-232$.

Jimoh, W.A., O.A. Fagbenro, and E.O Adeparusi. (2014). Response of African Catfish, Clarias gariepinus (Burchell 1822), Fingerlings Fed Diets Containing Differently Timed Wet-Heat-Treated Sesame (Sesamum indicum) Seedmeal. Agricultural Sciences, 5, 1159-1171. 
Kenan K. and Ö .yașar (2005). Apparent digestibility of selected feed ingredients for Nile tilapia (Oreochromis niloticus). Aquaculture $250,308-316$.

Li K, Y.Wang, Z-X. Zheng, R-L. Jiang and . N-X .Xie. (2009). Replacing fish meal with rendered animal protein ingredients in diets for Malabar grouper, Epinephelus malabaricus, reared in net cages. J World Aquacult Soc 40: 67-75.

Lim C.E. and C.D. Webster .(2006). Nutrient requirements. In: C.E. Lim and C.D. Webster (eds.). Tilapia: biology, culture and nutrition. Food Products Press, New York, 469-501 .

Lindsay, G.J.H., M.J. Walton, J.W. Adron, T.C. Fletcher, C.Y. Cho and C.B Cowey. (1984). The growth of rainbow trout (Salmo gairdneri) given diets containing chitin and its relationship to chitinolytic enzymes and chitin digestibility. Aquaculture 37, 315-334.

Maniruzzaman M. (2001). Polyculture of Pangasius sutchi with carps at a fish farm of saleque Enterprize Namopara, Rajshahi. MS Thesis. University of Rajshahi, Rajshahi, Bangladesh

Mohanta, K.N., S. Subramanian and V.S. Korikanthimath (2013). Evaluation of Different Animal Protein Sources in Formulating the Diets for Blue Gourami, Trichogaster Trichopterus Fingerlings. J Aquac Res Development, Vol.4 No.2

Mondal K., A. Kaviraj and P.K. Mukhopadhyay. (2008). Evaluation of fermented fish-offal in the formulated diet of the freshwater catfish Heteropneustes fossilis. Aquacult. Res 39: 1443-1449.

Muin, H., N.N.A. Fatah, M.H.M. Nor, and S.A Razak. ( 2013). Rice bran replacement in Clarias gariepinus fingerlings with Pleurotus florida stalk. Sains Malaysiana 42(8): 1109-1114.

New, M.B. and U.N. Wijkstrom .( 2002). Use of fishmeal and fish oil in aquafeeds: Further thoughts on the fishmeal trap. F.A.O fisheries circular No. 975. Rome: Food and Agriculture Organization of the United Nations.

Ng W.K., F.L. Liew, L.P. Ang, and K.W. Wong .(2001). Potential of mealworm (Tenebrio molitor) as an alternative protein source in practical diets for African catfish, Clarias gariepinus. Aquacult Res 32: 273-280.

NRC (1983). Nutrient Requirement of Fish. National Research Council, National Academy Press, Washington, DC, USA.

NRC (1993). Nutrient requirements of fish. National Research Council, National Academy Press, Washington, DC, USA.

Nwanna, L. C. (2003). Nutritional value and digestibility of fermented shrimp head waste meal by African catfish Clarias gariepinus. Pakistan Journal of nutrition, 2(6), 339-345.

Ogino, C., T. Takeuchi, H. Takeda and T. Watanabe. (1979). Availability of dietary phosphorus in carp and rainbow trout. Bulletin of the Japanese Society of Scientific Fisheries 45, 1527- 1532.

Ojewola G.S. and S.I Annah.(2006). Nutritive and Economic Value of Danish Fish Meal, Crayfish Dust Meal and Shrimp Waste Meal Inclusion in Broiler Diets International Journal of Poultry Science 5 (4): 390-394.

Okoye, F.C. (1998). The replacement value of Shrimp waste meal (SWM) for local fish meal (LFM) in the diet of broiler chicken. Proceeding of the Aniversary Conference. NSAP, P: 261.

Olomu, J.M. (1995). Monogastric Animal Nutrition. Principles and practice. 1st Edn. A. Jachem Production. P. 67-73, 164-175.

Omeru, E. D. and R. J Solomon (2016). comparative analysis on the growth performance of catfish (clarias gariepinus) fedwith earthworm as a replacement of fish meal. American Journal of Research Communication, 4(6): 89-125

Oresegun, A., O.R. Oguntadeand, O.A Ayinla (2007). A review of catfish culture in Nigeria. Nig. J. Fish., $4(1), 27-52$.

Otubusin, S.O., F.O., Ogunleye and O.T. Agbebi .(2009). Feeding trials using local protein sources to replace fishmeal in pelleted feeds in catfish (Clarias gariepinus Burchell 1822) culture. Euro J Sci Res 31: 142-147. 
Özdemir, Y., K. kÖprücü , E.Xeker, and M.N .akmak.(1999). An investigation on the nutrient quality of freshwater crayfish, Astacus leptodactylus ssp. (in Turkish), X. National symposium on aquatic products, 22-24 September, Adana, Turkey, pp. 385- 393.

Park, G. S., T. Takeuchi, T. Seikai and T. Yoshinaga. ( 2000). The effects of residual salts and free amino acids in mysid meal on growth of juvenile Japanese flounder (Paralichthys olivaceus). Nippon Suisan Gakkaishi 66(4):697-704.

Pyke, G.H.( 2008). Plague Minnow or Mosquito Fish? A review of the biology and impacts of introduced Gambusia species. Annual Review of Ecology, Evolution and Systematics 39:171-191.

Ramanchandran, N., P.T. Mathew, P. Madhavan and K..G. Prabhu (1987). Chitin as a feed additive for broiler chicken. Ind. J. Poult. Sci., 22: 40-44.

Robaina, L., F.J. Myano, M.S. Izquierdo, J. Socorro, J.M. Vergar and D . Montero. (1997). Corn gluten and bone meals as protein sources in diets for gilthead seabream (Sparus aurata): nutritional and histological implications. Aquaculture 157, 347-359.

Robinson E.H. and M.H. Li .(1998). Comparison of practical diets with and without animal protein at various concentrations of dietary protein on performance of channel catfish Ictalurus punctatus raised in earthen ponds. J World Aquacult Soc 29: 273-280.

Rodehutscord, M., Z. Gregus and E. Pfeffer. (2000). Effect of phosphorus intake on fecal and non-fecal phosphorus excretion in rainbow trout (Oncorchyncus mykiss) and the consequences for comparative phosphorus availability studies. Aquaculture 188, 383-398.

Sagarika S. S., K.Dinesh, V.R. Sreenath and G. Adnankhan .(2015). Exploring the Possibility of Dietary inclusion of Vegetable Waste in the Feed of Nile Tilapia, Oreochromis niloticus. Res. J. Recent. Sci., Vol. 4(ISC-2014), 8-13

Sakamoto, S. and Y. Yone. (1973). Effect of dietary calcium / phosphorus ratio upon growth, feed efficiency and blood serum Ca and P level in red sea bream. Bull. Jpn. Soc. Sci. Fish. 39, 343-348.

SAS (1999). Statistical Analysis Institute Inc. (SAS). Users guide. Version:9th Edition Statistical Analysis system Institute, Inc. Cary, NC, USA

Shearer, K.D., A. Maage ,J. Opstvedt, and H., Mundheim. (1992). Effects of high-ash diets on growth, feed efficiency, and zinc status of juvenile Atlantic salmon (Salmo salar). Aquaculture 106, 345-355.

Shiau S.Y. and H.S. Liang .(1994). Nutrient digestibility and growth of hybrid tilapia, Oreochromis niloticus x O. aureus as influenced by agar supplementation at two dietary protein levels. Aquaculture 127, 41-48.

Shiau, S.Y.and Y.P. Yu. ( 1999). Dietary supplementation of chitin and chitosan depresses growth in tilapia, Oreochromis niloticus x O. aureus. Aquaculture 179, 439-446.

Skonberg, D.I., L. Yogev, R.W. Hardy and F.M Dong.( 1997). Metabolic response to dietary phosphorus intake in rainbow trout (Oncorchyncus mykiss). Aquaculture 157, 11-24

Sotolu, A.O. .(2009). Comparative utilization of fish waste meal with imported fish meal by African catfish (Clarias gariepinus). Am-Euras J Sci Res 4: 285-289.

Sotolu, A.O. and E.O. Faturoti, (2008). Digestibility and Nutritional Values of Differently processed Leucaena leucocephala (Lam De Wit) Seed Meals in the Diet of African Catfish (Clarias gariepinus). Middle-East J. Sci. Res., 3(4): 190-199.

Spreen, K.A., J.P. Zikakis and P.R. Austin. (1984). Chitin Chitosan related enzymes. Proc. Int. U.S; Jpn Semin Adu. 57. Ed. Zikakis. J.P. Academic Orlando. Fla.

Swain, S., S. Shyama, K.. Dinesh, V.R. Sreenath and G. Adnankhan .(2015). Exploring the Possibility of Dietary inclusion of Vegetable Waste in the Feed of Nile Tilapia, Oreochromis niloticus. Res. J. Recent. Sci Vol. 4, 8-13

Toppe J., A.S. Aksnes, B. Hopeand and S. Albrektsen .(2005). Inclusion of fish bone and crab byproducts in diets for Atlantic cod ,Gadus morhua. AQUA Volume 253, Issues 1-4, Pages 636-645

Uys, W. (1989). Aspects of the Nutritional Physiology and Dietary Requirements of Juvenile and Adult Sharptooth Catfish Clarias gariepinus Pisces: Clariidae. Ph.D Thesis, Rhodes University, South Africa. 
Walker, W.H. , R.O. Smitherman and J.W. Avault. (1966).. Crawfish waste -Apotential for channel catfish.Louisiana Agriculture Winter, Volume 10,No.2,page 14-15.

Xuan, T.D., A.S. Tawata, T.D. Khann and I.M. Chung. ( 2005). Biological control of weeds and plants pathogens in paddy rice by exploiting plant allelopathy: An overview, Crop prot, 24: 127-206.

Yoshitomi, B., M. Aoki, S. Oshima, and K.. Hata. (2006). Evaluation of krill (Euphausia superba) meal as a partial replacement for fish meal in rainbow trout (Oncorhynchus mykiss) diets. Aquaculture 261, 440- 446.

\title{
تقييم بعض مصادر البروتين الحيواني كبديل لمسحوق السمك في اعداد علائق أسماك القرموط الأفريقي
}

\author{
محسن صالح حسين ، ، أحمد كامل ابر هيم الحمادي² و مصطقى قرني سيد طه2 \\ 1قسم الإنتاج الحيوانى - كلية الزراعة ـ جامعة الأزهر - القاهرة. \\ 2قتم تغذية الأسماك ـ المعهل القومي لعلوم البحار و المصايدـ القناطر الخيريةـ محافظة القليوبيةــ مصر.

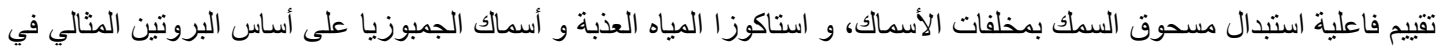

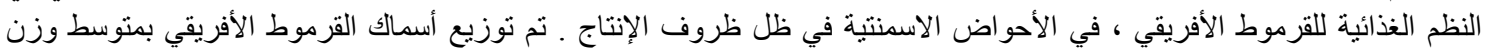

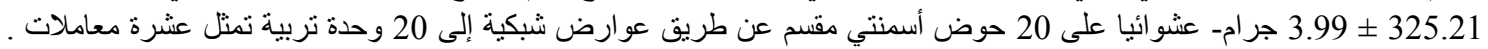

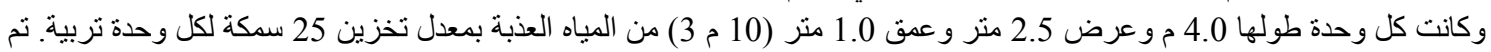

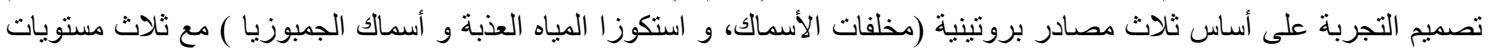 \\ احلال لبروتين مسحوق السمك (75،50 و 100٪) مع مر اعاة ثبات كل من تركيز بروتين الخام (37٪) والطاقة الكلية للعلائق المختبرة

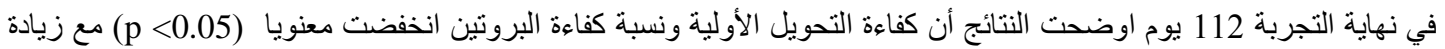

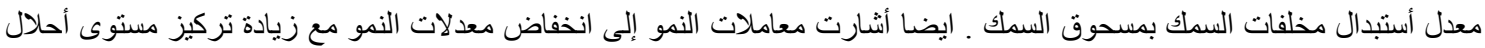

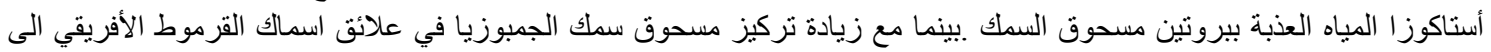

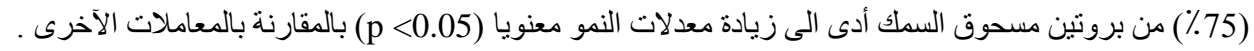

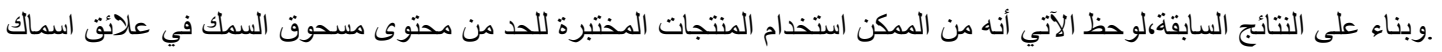

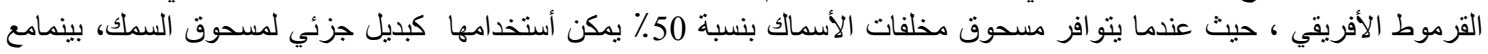

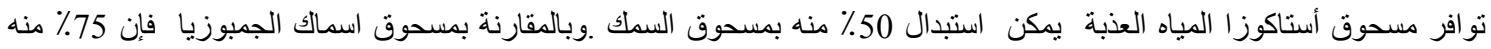

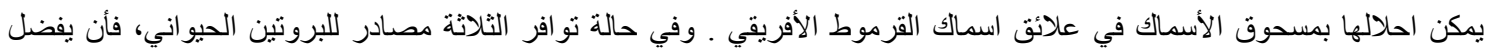 \\ استخدام مسحوق اسماك الجمبوزيا بنسبة احلال (75٪) لبروتين مسحوق السمك في علاك علائق اسماك القرموط الأفريقي .
}

